\section{Käsiteanalyysi työnohjauksesta}

Keski-Luopa, Leila (2018). Kohti kokonaisvaltaista työnohjauksen teoriaa. Työnohjaus intersubjektiivisena kehitysprosessina.

Metanoia Instituutti. 389 sivua.

\section{TEOS ON SOSIAALIPSYKOLOGIAN} väitöskirja, joka haastaa lukijan kaksoisrooliin: epäviralliseksi väitöskirjan esitarkastajaksi ja kirja-arvion tekijäksi.

Kuittaan paljon ajatuksia herättävän esitarkastajan roolin sillä havainnolla, että väitöskirjaan sisältyy teorian ja kokijan välinen sisäinen ristiriita. Tavoite on - kuten otsikkokin kertoo - laatia teoria työnohjauksesta.

Väitöskirja on täysin teoreettiskäsitteellinen, eikä siinä ole empiiristä aineistoa. Ristiriitaa syntyy siitä, että useissa kohdissa Leila Keski-Luopa käyttää teoriapohjaisessa työssään ilmaisua, joka viittaa haastatteluaineistoon siihen tapaan, että "työnohjaajat ajattelevat, toimivat, siirtävät seuraavalle työnohjaajapolvelle ja ymmärtävät työnohjauksen ilmiöitä tietyillä tavoilla”.

Hän tuo siis työnohjaajat kokijoina esille. Työnohjaajien ajattelua ja käsitemäärittelyjä ei väitöstutkimuksessa kuitenkaan tutkittu. Toistaiseksi ainut suomalainen väitöskirja, jossa on tutkittu empiirisesti haastatellen työnohjaajien käsitteellistä ajattelua, on Leena Ahteenmäki-Pelkosen tutkimus kirkon työnohjaajista vuodelta 2006. Sitä ei ole Keski-Luopan lähdeluettelossa.
TYÖNOHJAUKSELTA PUUTTUU TEORIATAUSTA

Kirjoittajan keskeinen väite on, että työnohjaus on hajaannuksessa, koska siltä puuttuu teoreettisesti jäsentynyt tausta. Hänen kunnianhimoinen tavoitteensa on luoda monitieteinen työnohjausprosessia kuvaava käsitteiden rakenne, jossa on otettava huomioon "psykologisia, kasvatustieteellisiä, sosiologisia, sosiaalipsykologisia, kulttuurihistoriallisia, kansatieteellisiä, filosofisia ja neurotieteisiä" näkökulmia.

Tekijän ominta näkökulmaa edustaa psykoanalyyttinen ajattelu, johon nojaudutaan teoksen useissa kohdissa. Lukija huomaa toivovansa, että kunpa joku analysoisi yhtä vastuullisesti työnohjausprosessia mutta käyttäisi teoreettisena tausta-ajattelunaan kognitiivis-konstruktiivista lähestymistapaa. Esimerkistä käy työnohjauksessa olennainen 'identiteetin' käsite - onhan niin ohjaajan kuin ohjattavan identiteetti ja sen muuttuminen merkittävä tekijä työnohjauksen tuloksellisuuden, toimivuuden ja vuorovaikutteisuuden kannalta.

Teoksessa on yksityiskohtainen ja laaja määrittely identiteetistä. Se painottuu varhaislapsuuden identiteetin rakentumiseen psykodynaamisen viitekehyksen

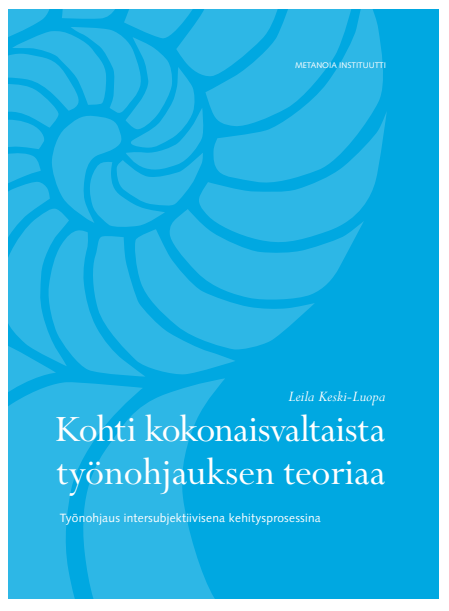

kautta. Aikuisen identiteetin rakentumisesta kognitiivisen ja sosiokonstruktiivisen käsitteistön jäsentämänä on viime vuosikymmenen aikana ilmestynyt runsaasti tieteellistä kirjallisuutta, jota toivoisi työnohjaajien osaavan löytää toimintansa tueksi.

\section{HISTORIA JÄSENTÄÄ TEOSTA}

Kirjan kantava teema on 1920-luvulta lähtevä analyysi työnohjauksen historiasta. Sen pohjalta kirjoittaja sijoittaa työnohjauksen tavoitteet ohjattavan kannalta kolmelle alueelle: työn sisältöä analysoivaksi, ahdistusta vähentäväksi eli kannattelevaksi toiminnaksi ja vapauttavaksi toiminnaksi.

Vastuullinen ja ammattimainen työnohjaaja pyrkii vaihtamaan joustavasti ja ohjattavaansa palvelevasti tavoitenäkökulmia samankin työnohjausistunnon aikana. Näin hän tuottaa työnohjaukseen syvällistä ja monipuolista ongelmanratkaisua ja aktivoi ohjattavaa jäsentämään työtilannettaan monesta suunnasta. 


\section{VASTUULLINEN TYÖNOHJAAJA VAIHTAA}

TAVOITENÄKÖKULMAA TARPEEN MUKAAN.
Teos avaa keskeisiä käsitteitä. Siinä määritellään käyttöteoriaa, puolustusmekanismeja, paralleeli-ilmiötä, tietoisuutta, identiteettiä, työnohjauksen sosiaalista rakennetta, persoonallisuuden kehittymistä, työnohjauksen ydinfunktioita, itsereflektiota, vuorovaikutusprosessia ja vastatunteita - kaikki olennaisia ja tarpeellisia käsitteitä, jotta ohjaaja voi kehittyä yhä taitavammaksi työssään.

\section{MAHTUUKO TYÖNOHJAUS YHDEN TEORIAN ALLE?}

Teosta voi suositella valistuneelle työnohjaajalle, joka haluaa analysoida omaa teoreettista ajatteluaan ja samalla työnohjaajatoimintansa käsitteellisiä perusteita. Se sisältää huomattavan sivumäärän tutkijalta edellytettävää pohdintaa tieteellisten menetelmien perusteista ja analyysitapojen käsitteellisistä rakenteista. Teos toimii siten pikemminkin käsikirjana kuin kannesta kanteen luettavana tietokirjana.

Olen toiminut yli 30 vuotta työnohjaajana ja työnohjaajien kouluttajana. Kokemukseni pohjalta olen Leila Keski-Luopan kanssa samaa mieltä siitä, että työnohjausprosessia tulee jäsentää yhä enemmän teoreettisin käsittein, jotta työnohjauksen vaikuttavuutta voidaan ennustaa sekä sen uskottavuutta, käytettävyyttä ja sovellettavuutta kuvata ja perustella vielä paremmin. Mutta onko mahdollista puristaa työnohjausprosessi yhden teorian alaisuuteen ja kuvata sen ilmiöitä vain yhden teoreettisen viitekehyksen kautta?

Kuvaisiko erilaisten teoreettisten viitekehysten, kuten psykodynaamisen ja kognitiivisen, vuoropuhelu vielä monipuolisemmin sitä vivahteikasta vuorovaikutusta, jossa ohjaaja ja ohjattava toimivat omine historioineen, omista kehityksellisistä lähtökohdistaan, omien sosiaalisten kontekstiensa ohjaamina ja omine persoonallisine piirteineen ja oppimistaitoineen?

\section{SOILI KESKINEN}

PsT, kasvatustieteen professori emerita, työ- ja organisaatiopsykologian dosentti

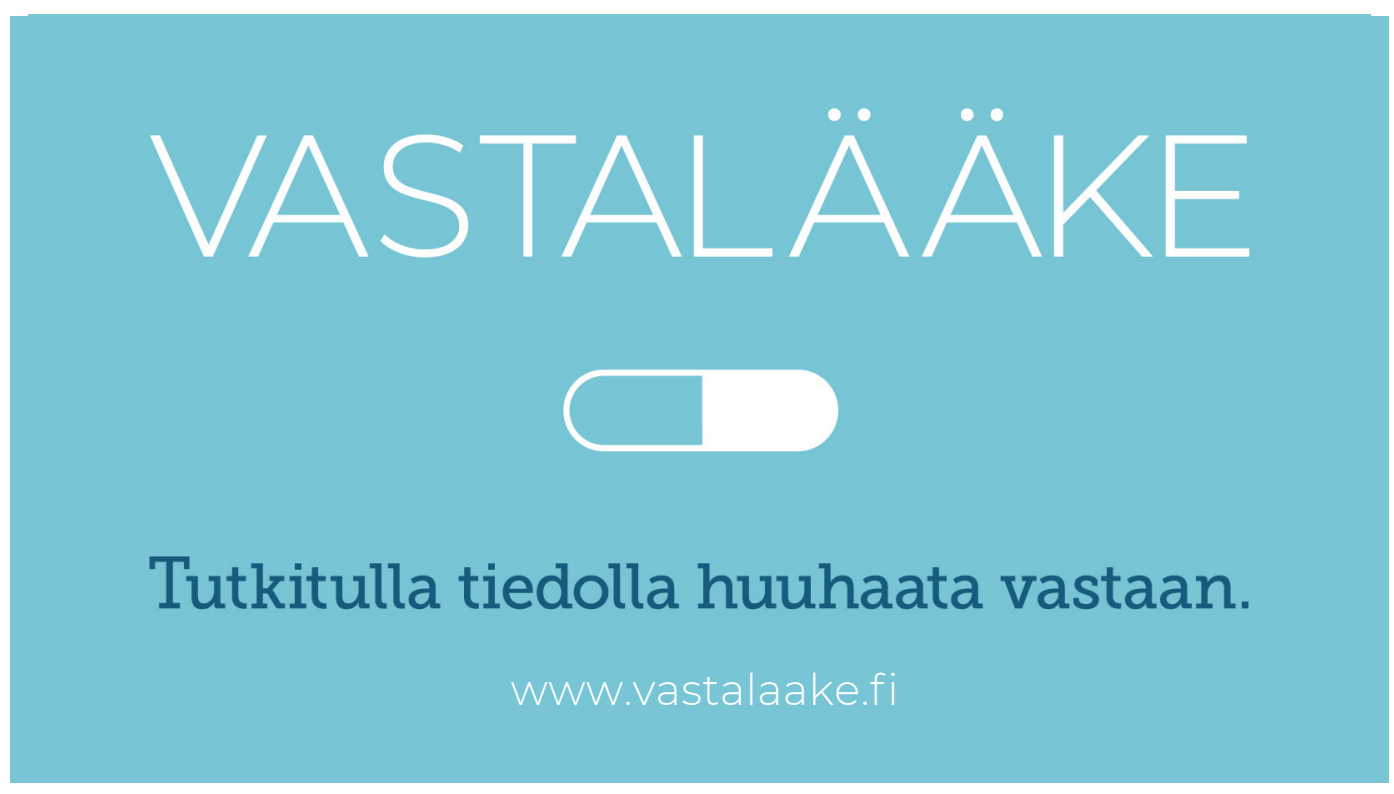

